\title{
A New Approach to Construct Diffusion/Permeation Cell for Use in Flow Systems. Application in the Spectrophotometric Determination of Bicarbonate Ions
}

\author{
Paulo C. C. de Oliveira, ${ }^{*, a}$ Jorge C. Masini, ${ }^{b}$ Cristiane X. Galhardo, ${ }^{a}$ José C. de S. Lima, ${ }^{c}$ \\ Antonio E. G. Sant'ana, ${ }^{a}$ Ana M. G. Vasconcelos, ${ }^{a}$ Wanessa P. Nunes ${ }^{a}$ and Osvaldo L. C. Amaral ${ }^{d}$ \\ ${ }^{a}$ Instituto de Química e Biotecnologia, Universidade Federal de Alagoas, Campus A. C. Simões, \\ Av. Lorival de Melo Mota, sn, Tabuleiro do Martins, 57072-970 Maceió-AL, Brazil \\ ${ }^{b}$ Instituto de Química, Universidade de São Paulo, CP 26077, 05513-970 São Paulo-SP, Brazil \\ ${ }^{c}$ Escola Agrotécnica Federal de Satuba, Satuba-AL, Brazil \\ ${ }^{d}$ Instituto do Meio Ambiente do Estado de Alagoas, Maceió-AL, Brazil
}

\begin{abstract}
Este artigo descreve uma nova abordagem para construção de módulos de difusão/permeação de gás, baseado no perfeito encaixe entre dois blocos de acrílico. A cela foi empregada para determinação de íons bicarbonato, explorando a descoloração de uma solução $0,01 \%$ (m/v) de fenolftaleína em meio alcalino ( $\mathrm{pH} 9,0)$. A variação da coloração do indicador foi monitorada em $552 \mathrm{~nm}$. A curva analítica exibiu faixa linear entre 25,0 e 150,0 mg L-1 em $\mathrm{NaHCO}_{3}$. Os sinais obtidos a partir de injeções consecutivas $(\mathrm{n}=10)$ de uma solução padrão $5,0 \mathrm{mg} \mathrm{\textrm {L } ^ { - 1 }}$ resultaram em desvio padrão relativo menor que 1,0\%. O coeficiente de correlação da curva analítica foi 0,9996 e o limite de detecção (3 x ruído/coeficiente angular) 4,41 $\mathrm{mg} \mathrm{L}^{-1}$ de $\mathrm{NaHCO}_{3}$. O método proposto é rápido (até 50 amostras/hora) e os resultados estão em boa concordância com os obtidos por titulação clássica.
\end{abstract}

This work describes a new approach for construction of gaseous diffusion/permeation module in a configuration based on the perfect fitting between two plaques of acrylic. It was employed to determine bicarbonate ions exploiting the discoloration of a $0.01 \%(\mathrm{~m} / \mathrm{v})$ phenolphthalein solution in medium of $1.0 \times 10^{-5} \mathrm{~mol} \mathrm{~L}^{-1} \mathrm{NaOH}(\mathrm{pH} 9.0)$. The variation in the indicator color was monitored at $552 \mathrm{~nm}$. The analytical curve showed a working range between 25.0 and $150.0 \mathrm{mg} \mathrm{L}{ }^{-1}$ in $\mathrm{NaHCO}_{3}$. Consecutive injections $(\mathrm{n}=10)$ of a standard $5.0 \mathrm{mg} \mathrm{L} \mathrm{NaHCO}_{3}$ solutions exhibited less than $1.0 \%$ of relative standard deviation. The correlation coefficient of analytical curve was 0.9996 and the limit of detection ( $3 \mathrm{x}$ noise/slope) is $4.41 \mathrm{mg} \mathrm{L}^{-1}$ in $\mathrm{NaHCO}_{3}$. The proposed method is rapid (50 sample/hour) and results were in good agreement with the ones obtained by classical titrimetry.

Keywords: gas-diffusion device, flow injection analysis, bicarbonate ions

\section{Introduction}

Phase separations associated to flow injection systems are strategies quite used to improve the selectivity of analytical methods, as well as to perform pre-concentration of chemical species. ${ }^{1-4}$ Phase separations involving liquid/ liquid,,$^{5-7}$ gas/solid and gas/liquid extractions ${ }^{8,9}$ are applied in many cases to eliminate chemical interferences and matrix effects. The applications of these approaches in flow injection systems reduce the time of analysis considerably,

*e-mail: pcco@qui.ufal.br making possible the direct analysis of complex samples, and saving sample and reagents..$^{10,11}$

The uses of gaseous diffusion module for the analytical control of chemical species contained in many commercial products are of great interest. Among that species are sulfite, ${ }^{12-14}$ carbonate and/or bicarbonate, ${ }^{15-17}$ ammonia, ${ }^{18-21}$ cyanide, ${ }^{22}$ nitrogen compounds, ${ }^{23}$ volatile organic molecules, ${ }^{24}$ sulfide, ${ }^{25,26}$ and others. These substances can occur either naturally, as in the case of the presence of bicarbonate in mineral waters, or they can be intentionally added to confer especial properties to the product, increasing the 
biochemical stability and chemical resistance to oxidation. The analytical control of those species by flow injection analysis is commonly made with the employment of gas/liquid separation module that usually consists of two plates separated by a membrane that is permeable to the generated gas. Those diffusion modules can be bought commercially, ${ }^{27,28}$ or can be home made,,$^{26,29-32}$ since they are easy to construct. However, the closedown of the diffusion system still consist a critical problem and little or no attention has almost been given to that subject.

A variety of gaseous diffusion cells were built with different geometries, but the most common of them consists of two half blocks on which are engraved channels that are mirror images of each other. An inlet and an outlet port extending from the channels are made in each block, which are held together tightly by screws to avoid leakages between the blocks and the sandwiched membrane. However, leaking problems frequently happen if the suitable number of screws is not used, hindering the execution of the analyses. The increment of the number of screws to guarantee a better closedown is an alternative quite adopted. However, the assembly and re-assembly operation is very slow, making maintenance a tedious task. Another inconvenience of that device is the appearance of unequal points of pressure along the cell, introducing leakage and poor repeatability, being critical in cells that make use of deformable materials to seal the plates.

In this work a new model of a gaseous diffusion module with linear geometry is proposed and evaluated in the determination of total alkalinity in samples of commercial mineral waters.

\section{Experimental}

\section{Reagents and solutions}

All reagents used were of analytical grade from Merck. Solutions were prepared with deionized water previously boiled to avoid interference of dissolved $\mathrm{CO}_{2}$.

A stock solution of sodium bicarbonate containing $1000 \mathrm{mg} \mathrm{L}^{-1}$ of bicarbonate was prepared weekly by dissolving $1.4002 \mathrm{~g}$ of anhydrous $\mathrm{NaHCO}_{3}$ in $\mathrm{CO}_{2}$-free deionized water, completing the volume to the mark of a $1 \mathrm{~L}$ in volumetric flask. Stock solution of $2.0 \mathrm{~mol} \mathrm{~L}^{-1}$ sulfuric acid was prepared by diluting $56.0 \mathrm{~mL}$ of the concentrated $98 \%(\mathrm{~m} / \mathrm{m})$ reagent (density of $1.98 \mathrm{~g} \mathrm{~mL}^{-1}$ ) to $500 \mathrm{~mL}$. Stock $0.01 \mathrm{~mol} \mathrm{~L}^{-1} \mathrm{NaOH}$ solution was prepared by dissolution of $0.1 \mathrm{~g}( \pm 1 \mathrm{mg})$ of $\mathrm{NaOH}$ in a $250 \mathrm{~mL}$ volumetric flask, diluting to the mark with $\mathrm{CO}_{2}$-free deionized water. Working $\mathrm{NaOH}$ solutions were prepared by adequate dilution of the stock solution using $\mathrm{CO}_{2}$-free deionized water.

The reagent $0.01 \%(\mathrm{~m} / \mathrm{v})$ phenolphthalein solution was prepared daily in presence of $1 \times 10^{-5} \mathrm{~mol} \mathrm{~L}^{-1} \mathrm{NaOH}$ by weighting $0.05 \mathrm{~g}( \pm 1 \mathrm{mg})$ of phenolphthalein, followed by dissolution in $0.5 \mathrm{~mL}$ of $0.010 \mathrm{~mol} \mathrm{~L}^{-1} \mathrm{NaOH}$ solution, with the final volume being completed to the mark of a $500 \mathrm{~mL}$ volumetric flask using $\mathrm{CO}_{2}$-free deionized water. Methyl red solution at concentration of $0.01 \%(\mathrm{~m} / \mathrm{v})$ was prepared by weighting and dissolution of $0.01 \mathrm{~g}( \pm 1 \mathrm{mg})$ of the indicator in $5.0 \mathrm{~mL}$ of ethanol $95 \%(\mathrm{v} / \mathrm{v})$ and completing the volume to the mark of a $100 \mathrm{~mL}$ volumetric flask using deionized water. This methyl red solution was used as indicator of final point in classical titrimetric analysis used for comparison with the proposed method.

The PTFE membranes used to diffusion/permeation of gas generated were acquired in local market. This membrane is the typical Teflon ${ }^{\circledR}$ plumbing tape.

\section{Equipment and accessories}

A four channels peristaltic pump from Ismatec ${ }^{\circledR}$ (model 78016-30) fitted out with Tygon ${ }^{\circledR}$ tubing $(0.8 \mathrm{~mm}$ i.d.) was used in all experiments. Transmission lines were made of polyethylene tubing of $0.7 \mathrm{~mm}$ i.d. A singlebeam Micronal ${ }^{\circledR}$ B382 spectrophotometer (Micronal, São Paulo, SP, Brazil) was used as detector with a Hellma ${ }^{\circledR}$ U-flow cell with $10 \mathrm{~mm}$ of light pathlength and $80 \mu \mathrm{L}$ of internal volume. Detection was made at $552 \mathrm{~nm}$ and the analytical readouts were recorded with a Hitachi ${ }^{\circledR}$ model 56 chart recorder.

\section{Construction of gas-diffusion device}

The gas-diffusion module is composed by two rectangular acrylic blocks with dimensions of $55 \times 16 \times$ $21 \mathrm{~mm}$. In one of the blocks (A) there is a longitudinal central channel with $6 \mathrm{~mm}$ of width and $5 \mathrm{~mm}$ deep, from an extremity to other of the piece. In the other block (B), a longitudinal lowering with $5.25 \mathrm{~mm}$ of width and $6 \mathrm{~mm}$ of depth was made in the two laterals, from one extremity to the other, so that this block inserts perfectly inside of the first. The dimensions of the central channels for the donor and receiving solution flows are $35 \times 2 \times 1$ (length, width and depth in $\mathrm{mm}$, respectively) in both blocks. The details of the cell are exhibited in Figure 1. To evaluate the performance of the new diffusion cell, analysis of total alkalinity in eight different commercial marks of mineral waters was performed. 


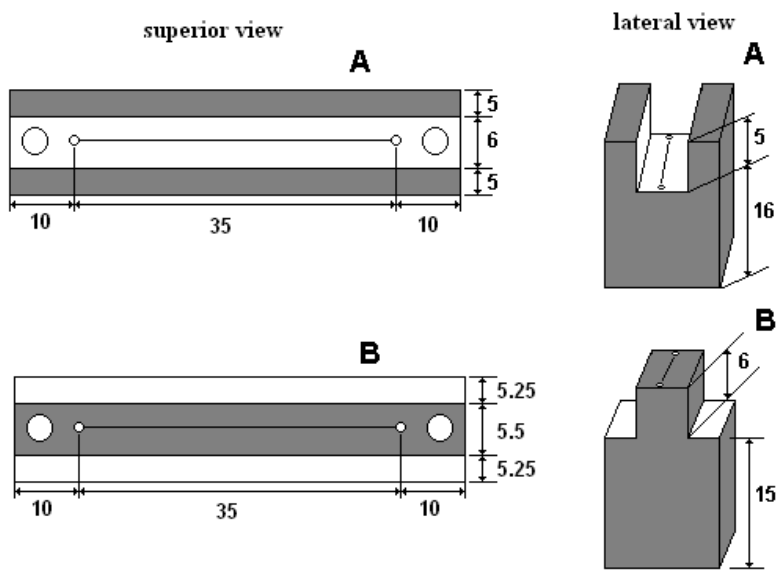

Figure 1. Gas-diffusion device built and applied for determination of bicarbonate ions (measurements in millimeter).

\section{Flow-injection system}

The analysis was based on monitoring the color fading of a $0.01 \%(\mathrm{~m} / \mathrm{v})$ phenolphthalein solution at $\mathrm{pH} 9.0$ in medium of $1 \times 10^{-5} \mathrm{~mol} \mathrm{~L}^{-1} \mathrm{NaOH}$, at $552 \mathrm{~nm}$. This solution reservoir is maintained closed to avoid $\mathrm{CO}_{2}$ absorption from the atmosphere and its preparation is carefully accomplished daily. During the analyses, the solutions are transported through the tubes of polyethylene and the contact of the solutions with the atmosphere is inexistent, eliminating the interference of atmospheric $\mathrm{CO}_{2}$. The concentration of carrier solution used $\left(\mathrm{H}_{2} \mathrm{SO}_{4}\right)$ was 0.20 $\mathrm{mol} \mathrm{L}^{-1}$ to assure that all bicarbonate ions were completely converted in $\mathrm{CO}_{2}$. The receptor stream was $0.01 \%(\mathrm{~m} / \mathrm{v})$ phenolphthalein in $1 \times 10^{-5} \mathrm{~mol} \mathrm{~L}^{-1} \mathrm{NaOH}$. The flow system manifold was assembled according to the Figure 2.

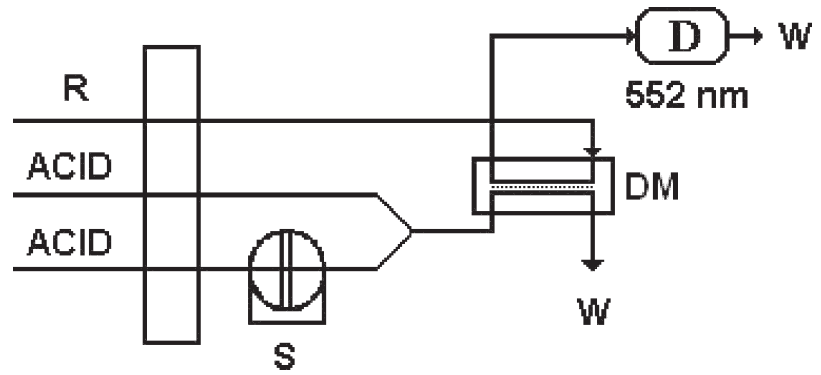

Figure 2. Manifold of flow injection system for determination of bicarbonate ions. $\mathrm{R}$ - phenolphthalein solution (in $\mathrm{pH}$ 9.0); ACID - $0.20 \mathrm{~mol}$ $\mathrm{L}^{-1} \mathrm{H}_{2} \mathrm{SO}_{4} ; \mathrm{S}$ - injection of sample/standard; DM - diffusion/permeation module; $\mathrm{D}$ - detector and $\mathrm{W}$ - waste. The rate flow of the solutions is $0.74 \mathrm{~mL} \mathrm{~min}^{-1}$.

\section{Samples treatment}

Eight different samples of mineral water were purchased from local market and analyzed directly, without previous chemical treatment.

\section{Results and Discussion}

\section{Optimization of experimental parameters}

The analytical signal in this work is the difference between the absorbances read at the maximum discoloration of the phenolphthalein solution and the base line. The optimization studies, aiming to maximize this discoloration, were accomplished by variation of the following experimental parameters: flow rate, concentration of sulfuric acid in donor stream, use of reaction coil after the confluence point between the carrier solution $\left(\mathrm{H}_{2} \mathrm{SO}_{4}\right)$, and the sample volume.

The flow rate of the donor and acceptor streams was varied between 0.73 and $1.45 \mathrm{~mL} \mathrm{~min}^{-1}$. The analytical signals decreased with the increase in the flow rates. At higher flow rates the residence time of the reaction mixture is reduced and, consequently, the time for $\mathrm{CO}_{2}$ exchange is shortened, leading to less intense discoloration of the phenolphthalein in the acceptor solution. Because the flow rate of $0.73 \mathrm{~mL} \mathrm{~min}^{-1}$ provided the largest analytical signal, it was used in the experiments.

The $\mathrm{H}_{2} \mathrm{SO}_{4}$ concentration in the donor stream was varied from 0.001 to $0.20 \mathrm{~mol} \mathrm{~L}^{-1}$ and its influence on the analytical signal was evaluated by injection of $120 \mu \mathrm{L}$ of a $20 \mathrm{mg} \mathrm{L}^{-1}$ bicarbonate standard solution at flow rate of $0.73 \mathrm{~mL} \mathrm{~min}^{-1}$. The analytical signal increased up to the sulfuric acid concentration of $0.01 \mathrm{~mol} \mathrm{~L}^{-1}$. Above this concentration, the analytical response remained constant, probably because the maximum conversion of $\mathrm{NaHCO}_{3}$ to dissolved gaseous $\mathrm{CO}_{2}$ is reached in the residence time of the flow system. However, because the concentration range of bicarbonate ions explored in the determinations were from 25 to $150 \mathrm{mg} \mathrm{L}^{-1}$, a $0.20 \mathrm{~mol} \mathrm{~L}^{-1}$ sulfuric acid carrier solution was used in the construction of analytical curve to assure complete conversion of $\mathrm{HCO}_{3}^{-}$into $\mathrm{CO}_{2}$.

No significant effect of the reaction coil length was observed on the analytical signal, although the absence of a reaction coil caused a small increase in absorbance variation, a fact that may be explained by the reduced dispersion of the reaction zone. Longer reaction coils facilitate the quantitative conversion of $\mathrm{NaHCO}_{3}$ into gaseous $\mathrm{CO}_{2}$, but also increase the dispersion in the flow system. The next experiments were performed in absence of the reaction coil, since under this condition there was a small improvement in the analytical response and in the analytical throughput.

The influence of sample volume was studied in the range between 25 and $200 \mu \mathrm{L}$. As expected, the increase of sample volume increased the analytical signal, since larger amounts of $\mathrm{CO}_{2}$ diffused through the membrane. As a compromise between sensitivity and sampling throughput, a sample 
volume of $125 \mu \mathrm{L}$ was chosen to perform the real sample analyses. In this experiment and in the construction of the reference curve, as well as in the analyses of real samples, the concentration of carrier solution was $0.20 \mathrm{~mol} \mathrm{~L}^{-1} \mathrm{H}_{2} \mathrm{SO}_{4}$ to assure a large excess of this reagent and quantitative conversion of bicarbonate in $\mathrm{CO}_{2}$.

The following experimental conditions were adopted in the optimized method applied to samples of mineral

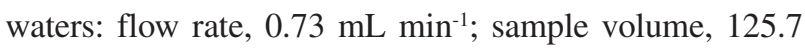
$\mu \mathrm{L}$; concentration of sulfuric acid in carrier stream and donor solution, $0.20 \mathrm{~mol} \mathrm{~L}^{-1}$. The manifold was configured connecting directly the acceptor stream outlet of the gas diffusion device to the detector flow cell, without a reaction coil after confluence point between the sample injection and carrier stream $\left(\mathrm{H}_{2} \mathrm{SO}_{4} 0.2 \mathrm{~mol} \mathrm{~L}^{-1}\right)$.

\section{Figures of merit}

The correlation between the points in the reference curve and concentration range of sodium bicarbonate studied (from 25 to $150 \mathrm{mg} \mathrm{L}^{-1}$ ) was very good, with linear correlation coefficient of 0.9996 . The analytical curve exhibited the following equation: $|\mathrm{S}|=2.0 \times 10^{-4}( \pm 1.0 \times$ $\left.10^{-5}\right) \mathrm{C}-5.0 \times 10^{-4}\left( \pm 8.0 \times 10^{-4}\right)$, where $|\mathrm{S}|$ is the analytical signal (absolute value) and $\mathrm{C}$ is the concentration of $\mathrm{NaHCO}_{3}\left(\mathrm{mg} \mathrm{L}^{-1}\right)$. The limit of detection computed from the regression parameters ${ }^{33}(3 \times$ noise/slope $)$ was 4.41 $\mathrm{mg} \mathrm{L}^{-1}$ of bicarbonate. The results presented good repeatability, and the relative standard deviation for 10 consecutive measurements of a standard $5.0 \mathrm{mg} \mathrm{L}^{-1}$ bicarbonate solution was smaller than $1.0 \%$. An analytical throughput of 50 samples per hour was possible with the proposed method.

\section{Analysis of waters samples}

Samples were directly injected in the flow system, without the need of previous chemical treatment. Eight different samples of commercial mineral water were analyzed and the found results were compared with the ones obtained by classic acid-base titrimetric method, using methyl red as indicator. Table 1 shows the results obtained for the determination of bicarbonate in the different analyzed samples.

The results originated from proposed method using the new gas diffusion module are in good agreement with the experimental values found by the conventional titrimetric method. A significance test (regression curve) was applied to verify if there are evidences of statistically significant differences between the two methods. ${ }^{33}$ Because the slope does not differ significantly from 1 and the intercept does not differ significantly from 0 at the 95\% confidence level, there is no evidence of significant differences between the two methods.

Table 1. Results obtained for analysis of different mineral commercial waters

\begin{tabular}{|c|c|c|}
\hline \multirow[t]{2}{*}{ Sample } & \multicolumn{2}{|c|}{ Concentration of $\mathrm{NaHCO}_{3} /\left(\mathrm{mg} \mathrm{L}^{-1}\right)$} \\
\hline & Proposed Method & Classical Titrimetry \\
\hline 1 & $54 \pm 4$ & $43 \pm 4$ \\
\hline 2 & $65 \pm 4$ & $70 \pm 4$ \\
\hline 3 & $77 \pm 4$ & $77 \pm 3$ \\
\hline 4 & $94 \pm 3$ & $100 \pm 3$ \\
\hline 5 & $102 \pm 3$ & $98 \pm 2$ \\
\hline 6 & $105 \pm 3$ & $101 \pm 4$ \\
\hline 7 & $161 \pm 5$ & $159 \pm 2$ \\
\hline 8 & $206 \pm 10$ & $199 \pm 6$ \\
\hline
\end{tabular}

The values are the average of three determinations for each sample.

\section{Conclusions}

The diffusion module proposed innovates in two aspects: the first one is the absence of deformable components as split or rubber, because the own ribbon of Teflon ${ }^{\circledR}$ acts as sealing and separation membrane. The second aspect concerns the assembly of the module, which is based on the perfect insertion of the blocks and, not by direct and simple overlap of the blocks as it is usually observed in models with linear geometry. The conformation of the built module guarantees a uniform distribution of pressure along the donor and acceptor flow channels. As consequence, the number of screws can be drastically reduced (only two in case of cells of small length), and maintenance is made easily, because the assembly and disassemble process is quite simple and fast. Leaking problems were not observed, demonstrating that the gas diffusion module proposed eliminates one of the most critical problems presented in other models of manufactured device for gaseous diffusion. The proposed method is fast, precise and practical (up to 50 sample/ hour) and uses the phenolphthalein, an acid-base indicator of low cost and easy acquisition.

\section{Acknowledgments}

The authors thank the Conselho Nacional de Desenvolvimento Científico e Tecnológico (CNPq), the Fundação de Amparo à Pesquisa do Estado de Alagoas (FAPEAL), the Fundação de Amparo à Pesquisa do Estado de São Paulo (FAPESP) for the financial support, and to Mr. Paulo Pinto da Silva of the Laboratory of Molecular Espectroscopia of the São Paulo University by manufacturing the gas-diffusion device. 


\section{References}

1. Ruzicka, J.; Hansen, E. H.; Flow Injection Analysis (Chemical Analysis Series), $2^{\text {nd }}$ ed., John Wiley \& Sons: New York, 1988, vol. 62.

2. Fang, Z.; Flow Injection Separation and Pre-concentration, VHC: Weinheim, 1993.

3. Cardwell, T. J.; Cattrall, R. W.; Mitri, M.; Talanta 1994, 41, 115.

4. Valcárcel, M.; Luque de Castro, M. D.; J. Cromatogr. 1987, 393, 3.

5. KubáH, V.; Crit. Rev. Anal. Chem. 1991, 22, 477.

6. Comitre, A. L. D.; Reis, B. F.; Talanta 2005, 65, 846.

7. Facchin, I.; Pasquini, C.; Quim. Nova 1998, 21, 60.

8. Zhi, Z.; Rios, A.; Valcárcel, M.; Crit. Rev. Anal. Chem. 1996, 26, 239.

9. KubáH, V.; Crit. Rev. Anal. Chem. 1992, 23, 323.

10. Pasquini, C.; Silva, M. C. H.; J. Braz. Chem. Soc. 1999, $10,85$.

11. Moskvin, L. N.; Nikitina, T. G.; J. Anal. Chem. 2004, 59, 2.

12. Atanassov, G. T.; Lima, R. C.; Mesquita, R. B. R.; Rangel, A. O. S. S.; Tóth, I. V.; Analysis 2000, 28, 77.

13. Sullivan, J. J.; Hollingworth, T. A.; Welell, M. M.; Newton, R. T.; Larose, J. E.; J. Assoc. Off. Anal. Chem. 1986, 69, 542.

14. Segundo, M. A.; Rangel, A. O. S. S.; Anal. Chim. Acta 2001, 427, 279.

15. Oshima, M.; Wel, Y.; Yamamoto, M.; Tanaka, H.; Takayanagi, T.; Anal. Sci. 2001, 17, 1285.

16. Satienperakul, S.; Cardwell, T. J.; Canttrall, R. W.; McKelvie, I. D.; Taylor D. M.; Kolev D.; Talanta 2004, 62, 631.

17. Grassi, V.; Miyazawa, M.; Pavan, M. A.; Kamogawa, M. Y.; Quim. Nova 2002, 25, 149.

18. Su, X.; Yu, B.; Tan, H.; Yang, X.; Nie, L.; Yao, S.; J. Pharm. Biomed. Anal. 1998, 16, 759.
19. Mana, H.; Spohn, U.; Fresenius' J. Anal. Chem. 2000, 366, 825.

20. Pasquini, C.; Faria, L. C.; Anal. Chim. Acta 1987, 193, 19.

21. van Son, M.; Schothorst, R. C.; den Boef, G.; Anal. Chim. Acta 1993, 153, 271.

22. Nomura, Y.; Nagakubo, K.; Jl, H.; Watanabe, A.; Akimoto, T.; Mcniven, S.; Arikawa, Y.; Karube, I.; Environ. Sci. Technol. 2000, 34, 2618.

23. Frenzel, W.; Schulz-Brssel, J.; Zinvirt, B.; Talanta 2004, 64, 278.

24. Tubino, M.; Barros, F. G.; J. Assoc. Off. Anal. Chem. 1991, 74, 346.

25. Armas, G.; Ferrer, L.; Miró, M.; Estela, J. M.; Cerdá, V.; Anal. Chim. Acta 2004, 524, 89.

26. Silva, M. S. P.; Masini, J. C.; Quim. Nova 2004, 27, 545.

27. Pavon, J. L. P.; Gonzalo, E. R.; Christian, G. D.; Ruzicka, J.; Anal. Chem. 1992, 64, 923.

28. http://www.globalfia.com, Globalfia - Supplier of FIA/SIA Instruments and Components, at in Buy - Manifold Devices Membrane Sampling Devices, accessed in June 2005.

29. Kierstan, K. T. E.; Beezer, A. E.; Mitchell, J. C.; Hadgraft, J.; Raghavan, S. L.; Davis, A. F.; Int. J. Pharm. 2001, 229, 87.

30. Mattos, I. L.; de Castro, M. D. L.; Valcárcel, M.; Talanta 1995, $42,755$.

31. Grassi, V.; Miyazawa, M.; Pavan, M. A.; Kamogawa, M. Y.; Quim. Nova 2002, 25, 149.

32. Mattos, I. L.; Queiroz, R. R. U.; Quim. Nova 1998, 21, 202.

33. Miller, J. C.; Miller, J. N.; Statistics for Analytical Chemistry, Ellis Horwood: Chichester, 1988.

Received: September 14, 2005 Published on the web: July 6, 2006

FAPESP helped in meeting the publication costs of this article. 